\title{
From Open Data to Smart City Governing Innovation in the Rennes Metropolitan Area (France)
}

\author{
Marie-Anaïs Le Breton, ESO Laboratory, University of Rennes, France \\ Mathilde Girardeau, PREFics Laboratory, University of Rennes, France \\ Helene Bailleul, ESO Laboratory, University of Rennes, France
}

\begin{abstract}
This article is the result of an action-research carried out on the territory of the Rennes metropolis (SmartRennes project). The authors propose a description and analysis of the governance of the smart city based on qualitative approach. Contrary to the idea of a centralised smart city strongly managed by one public actor, they note that the Rennes-style smart city is the result of governance distributed between different poles. They provide complementary methods of description of this governance: a historical vision of smart city actions and measures, an analysis of the values and issues raised by the stakeholders, and a network analysis of governance. Based on qualitative surveys, these results demonstrate the value of a monographic approach in the study of urban innovation and smart city.
\end{abstract}

\section{KEYWORDS}

Brittany, France, Governance, Historic Perspective, Mixed Methods, Monograph, Network Analysis, Public Players, Smart City

\section{INTRODUCTION}

Since the early 2000s, the Rennes metropolitan area's local authority (now Rennes Métropole) has launched major reflection on urban data toward applications dedicated to urban management and planning (Bailleul and Gibon, 2013). In 2017 Rennes Métropole launched the project of Metropolitan Public Service for Data (SPMD) and signed a partnership with Dassault Systèmes to experiment a 3D platform entitled 3DEXPERIENCity ${ }^{\circledR}$ Virtual Rennes. These two events are just the tip of the iceberg of the intense activity surrounding the smart city initiative of the Breton metropolitan area. The implementation of this process, which has been supported by the French State, Région Bretagne (the regional council of Brittany) and the European Union, has led to various partnerships with industry, the public sector, associations and academia. 10 years of building of a local smart city policy could therefore be examined through the multiple technological innovation implemented, but also from an organisational viewpoint. In the case of Rennes, several dozen projects have given substance to the process and question at various levels the urban governance (Pinson, 2010) that has led to its emergence over time. This observation alone could lead to the conclusion that there is a kind of improvisation 
in the implementation of the smart city. We are trying to overcome this intuition by deciphering the process implemented, its organisation and its shared objectives.

In addition, we assume that the values associated with the smart city by the stakeholders involved, the perceptions and controversy linked to the organisational changes, and their consequences on the network of players, may cause tensions and thus explain the complexity of the approach. It is therefore necessary to consider to what extent these legacies and experiences of the past 10 years have been integrated into the smart city process of Rennes Métropole. What is their impact on the formatting and meaning given to a 'Rennes-style' smart city approach?

The SmartRennes action-research project led by a multidisciplinary research team in partnership with Rennes Métropole, aims to shed light on these issues. Bringing to light the history of the 'Rennesstyle' smart city, from data management to a strategic metropolitan project, provides insight into the processes leading to the definition of its objectives and challenges.

The deployed digital devices seem to solidify the differences of opinion and tensions surrounding the visions of the smart city. That's why the following questions must be asked: who is the driving force and for what purpose? Which governance for a public control of smart city initiatives?

The purpose of this article is then to present the results of a monographic investigation dealing with 'smart city policy' design. This local focus enables to show the difficulties encountered in applying the smart city model in a particular context. We will demonstrate the emerging disparity between the initial vision of the smart city, greatly influenced by industrial players, and its political translation in a French context where public players are at the forefront and intend to steer the process. This research aims to complete the work on the differentiated appropriation of the smart city in European cities (Fernandez-Anez et al., 2018; Desdemoustier et al., 2019; Nesti, 2020).

Firstly, the review of literature revisits the construction of smart city's notion and highlights its complex translation into metropolitan policy. Academic controversy concerning the term and its implementation allow us to advocate for a qualitative approach as a monograph of Rennes smart city inititative. The position of public player is also major issue in academic works (Santinha et al., 2010; Nam et al., 2011; Angelidou, 2014). Thus, given the digital solutions provided by companies, can the public player be the driving force behind the smart city, or just a simple partner?

Then, interviews and analyses carried out in the SmartRennes research are mobilised. On the one hand, analysis of the two digital platforms implemented since 2017 allows to describe the numerous issues (data property, environmental performance, behavior changes, public services...) related to the smart city process and the role expected of public players in this specific context. On the other hand, discourse analysis allows to describe and visualise the values and opinions evoked by the smart city for professional stakeholders (Desdemoustier et al., 2019). The visualisations obtained will make it possible to discuss the definition of the 'Rennes-style' smart city, by identifying the recurring points and themes on which there is consensus, or on the contrary, those subject to controversy. Lastly, network analysis will allow the graphic visualisation of the stakeholders in order to highlight their role and connections. By insisting on the methodological stakes of such an analysis, we also wish to participate in the comprehensive approach of the smart city (Kummitha \& Crutzen, 2017).

\section{SMART CITY AND GOVERNANCE}

\subsection{From The Birth of The Concept}

The expression 'smart city' was initially developed by economic players in the form of a label, and thus refers to a hypermodern vision of an equipped city whose infrastructure is 'augmented' by digital tools (applications, captors, platforms, IoT, etc.): “'smart' refers to intelligent-acting products and services, artificial intelligence, and thinking machines" (Nam and Pardo, 2011). The economic stakes are indeed high for digital companies (in the broad sense of the term), which, after the 2008 economic crisis, saw the cities as a new market to be conquered. While local authorities 
are increasingly challenged to optimise the tools for urban action in a global context of dwindling resources, they are now being solicited by a variety of companies (start-ups, SMEs, large groups, etc.) that are developing technological solutions: "the smart city provides new instrumentation that enables observation of urban systems at a micro-level" (Harrison and Donnelly, 2011). Therefore, digital tools would be, in a sort of life-saving myth, the solution par excellence to improve urban management. Instrumentation of the city, of its equipment and infrastructure, is a driver of economic development and commercial influence for companies that are tending towards enhancing a form of 'commodification' of digital innovation. 'Performance' and 'profitability' are thus promised to public players through the development of interconnected tools that are described as intelligent by their developers. "Within this framework, the smart city turns out to be a "virtuous' collective imagination: that of a promising city of the future, currently in the making, thanks to the reasoned application of new digital technologies" (Lussault, 2018).

The dissemination of this concept owes its swiftness to the numerous international rankings of the 'smartest' cities. While placing cities in an economic rationale of competition (Anthopoulos et al., 2014), these rankings provides high visibility to the companies that contributed to their digital equipment. The digitalisation of the framework of urban planning (smart urbanism), highlighted in these rankings, are a means for local authorities to show themselves as being modern, in a technophile interpretation. These rankings are also the opportunity for cities, and often metropolitan areas, to join a globalised network and to access events, such as international trade fairs, that act to 'showcase' the urban area and the solutions developed in partnership with selected economic players. A principle of mimicry (Eveno, 2018) is thus created and makes the 'smart city' concept a model of economic and urban development. This territorial context provides a particularly good breeding ground for the economic development of 'digital giants' (Big Five, Waze, Airbnb, etc.), which, by creating direct relations with users, tend to modify the historic relationships that may have been established within the framework of public-private partnerships. In fact, whereas some years ago local authorities structured their relations with companies mainly through public procurement for the development of services, today companies develop innovative services directly aimed at the inhabitants. These new services are developed without any contractual relationship with the local authorities, therefore outside any political regulation (Courmont et al., 2019).

The literal definition of the term 'smart city' which constitutes an "argument to convince the territorial stakeholders to launch a policy towards the transformation of their city into an 'intelligent' entity" (Eveno, 2018, p.34), is linked to the initiators of the concept. From its dissemination by the economic world to its reuse by the political world, this concept has been translated and interpreted in numerous ways by bearing in mind the goals of better urban management using digital tools. The literal application of the concept remained relatively techno-centred for a long time, where the city was considered as an autonomous system: 'the concepts of 'smart' and 'intelligent' cities both describe an urban system of systems that modifies its behaviour in response to changes in the environment monitoring its various components and acting accordingly to potential or actual changes of state in order to achieve a desired goal" (Yovanof and Hazapis, 2009, p.448). The implementation of digital tools is at this early time dedicated to supporting the decision-making process, in the interest of optimising the local authority's financial and human resources. Citizens are here considered as users and consumers of urban services. The implementation of a smart city thus also presumes adaptation to their needs and expectations: "a city that monitors and integrates conditions of all of its critical infrastructures (...) can better optimize its resources, plan its preventive maintenance activities, and monitor security aspects while maximizing services to its citizens" (Hall, 2000, p.1). So this figure of the citizen is called into question, insofar as it would dismiss the place considered essential "of women, of men, of citizens" in urban governance by reducing them to being service users. 


\subsection{To It's Translation By The Political and Academic Spheres: The 'Humanisation' of The Smart City}

In the contrary, current research in human and social sciences urges us to question the dissemination of a techno-centred approach (Kummitha et al., 2017; Fernandez et al., 2018; Rumpala, 2018; Morozov et al., 2018). These authors defend a certain 'humanisation' of the smart city, in particular through criticism of "its main advocates, whether industrial or institutional, [who] mostly conceive (and perceive) the city as an immense urban system made up of human, material and information flows. Their goals are to facilitate and optimise these flows, in other terms, to manage them, to secure them, to regulate them, in short, to control them" (Lucas, 2014, p.81). Human actions raise the question of the link between what is technical and the place given to inhabitants in the implementation of this territorial approach. Furthermore, a city is considered as 'smart' "when investments in human and social capital and traditional (transport) and modern (ICT) communication infrastructure fuel sustainable economic growth and a high quality of life, with a wise management of natural resources, through participatory governance" (Caragliu et al., 2009, p.50). The introduction of the issue of governance shows that it is then necessary to think about its implementation globally, with local players. Through this mindset, a shift occurs, from the smart city as an urban territory augmented through digital technology to a city where all its stakeholders (public, private, associations, civil society) are aware and involved in the innovative handling of challenges and issues (Slotterback, 2011; Linders, 2012; Kleinhans et al., 2015). The implementation of smart city through participative governance therefore becomes closely linked to the political design where it is no longer just a question of using digital tools, but also to live better in it: "the 'real' smart city might use IT to enhance democratic debates about the kind of city it wants to be and what kind of city people want to live in" (Hollands, 2008, p.315).

It is also important to underline the ability of public players involved in a smart city policy to recognise citizens' expertise as users (Morozov et al., 2018), which should be surveyed in order to better understand the needs and adapt the provision of urban services in the most relevant way. The smart city could in fact be a co-constructed city, where the inhabitants' experience becomes central to the formulation of public policies (Falco et al., 2018; Rumpala, 2018). The public authorities would take part in a change of paradigm, moving from 'user-centric' to 'citizen-centric' viewpoint ${ }^{2}$. ICTs should make it possible to develop new forms of consultation and support the co-formulation and co-management of public and private services: used in an inclusive rationale of the right to the city for all and not with the goal of implementing a technophile or 'computer' city. The stakeholders taking part in these 'intelligent cities' therefore seek to provide the tools allowing inhabitants to make visible their local knowledge, and their wishes for the implementation of a smart city in a prospective approach (Morozov \& Bria, 2018).

The 'smart city' approach in Europe and more particularly in the case of France, seems to be closely linked to the exercise of democracy. Its political translation by French local authorities is intrinsically linked to the issue of citizen empowerment. The digital technologies acquired and developed in metropolitan areas aim to tackle the challenges of the disintermediation of individuals, and of low participation in urban government (Walters, 2011). The will to create inclusive city, based for example on the provision of open data, strongly inspires European smart cities. It is therefore appropriate to question the mechanisms, especially legislative, that led to this specificity of French smart city environment: a strong public data management (Box 1).

\section{THE STUDY DATA}

\subsection{The Ongoing Policy Design of The 'Smart City' in Rennes Métropole}

While the recent evolution of the legislative context (Box 1) is one of the explanatory factors of the significant importance of data issue in French metropolitan areas, for Rennes Métropole it has been a major issue for about twenty years (Box 2). In fact, Rennes Métropole has decided to engage in open 


\section{Box 1: The evolution of legislative environment of public data in France}

In order to foster protection of the environment, the European Commission Directorate-General for the Environment published the 'INSPIRE' Directive (2007/2/EC) on 14 March 2007. This promotes the creation in Europe of an infrastructure for spatial information. Three years later, through the Decree of 21 October 2010, this directive was transposed into French law. Since then, the data has become an important topic at both regional and national levels. Three major building blocks can be identified from the year 2011 onwards. Firstly, the creation of a single interministerial portal (data.gouv.fr), destined to gather and make freely available all of the state's public information. Next, two examples of decrees aimed at dealing with the growing demand for public data (by administrations, but also by citizens): the Decree of 21 February 2011 validating the creation of "Mission Etalab" (in charge of coordinating the action of French administrations for opening up data), and the Decree of 26 May 2011 relative to the reuse of public information held by the state and its public administrative institutions. The French policy of open data translates the transformation of public administrations and the availability for a whole set of stakeholders to become involved in the data governance. Since the 2000's data became quickly a 'stately affair': "Internet must be made to serve reform of the State"3. More recently, the 'Lemaire' Act 'for a Digital Republic' (promulgated on 7 October 2016) demonstrates the will to regulate the use of data by private players, in the interest of protecting citizens. It helps to make data a core part of public service. Since 25 May 2018, data processing is governed by a national regulatory text, the General Data Protection Regulation (GDPR). The French Data Protection Authority (CNIL) supports regional and local authorities in ensuring their compliance with this European text. In a certain manner, the general awareness of data (protection, security and its economic value) has increased the power of French regulatory authorities (CNIL, CSA, ARCEP).

data since the early 2000s. In 2010, over a hundred data sets were made accessible via the first French open data portal entitled 'Rennes Métropole en accès libre' (free access to Rennes Métropole [data]). This digital media embodied a political will and a shared ambition for transparency of public action, from the perspective of fostering the creation of urban services for citizens (Le Corf, 2016). This event is a key factor to understanding the 'political problem setting' (Eveno, 2018) of Rennes smart city (Figure 1). The open data portal is the first step in a set of interconnected devices, which have since been experimented and developed through infrastructures, platforms and digital applications, Fab Lab network as well as pedagogical events.

Since 2010 the considerations made based on management of urban data have significantly helped to translate the concept of 'smart city' into a political issue, and then to its appearance on the political agenda. However, this appearance is the result of a long process which shows that the formulation of a smart city approach depends on a certain number of parameters. 


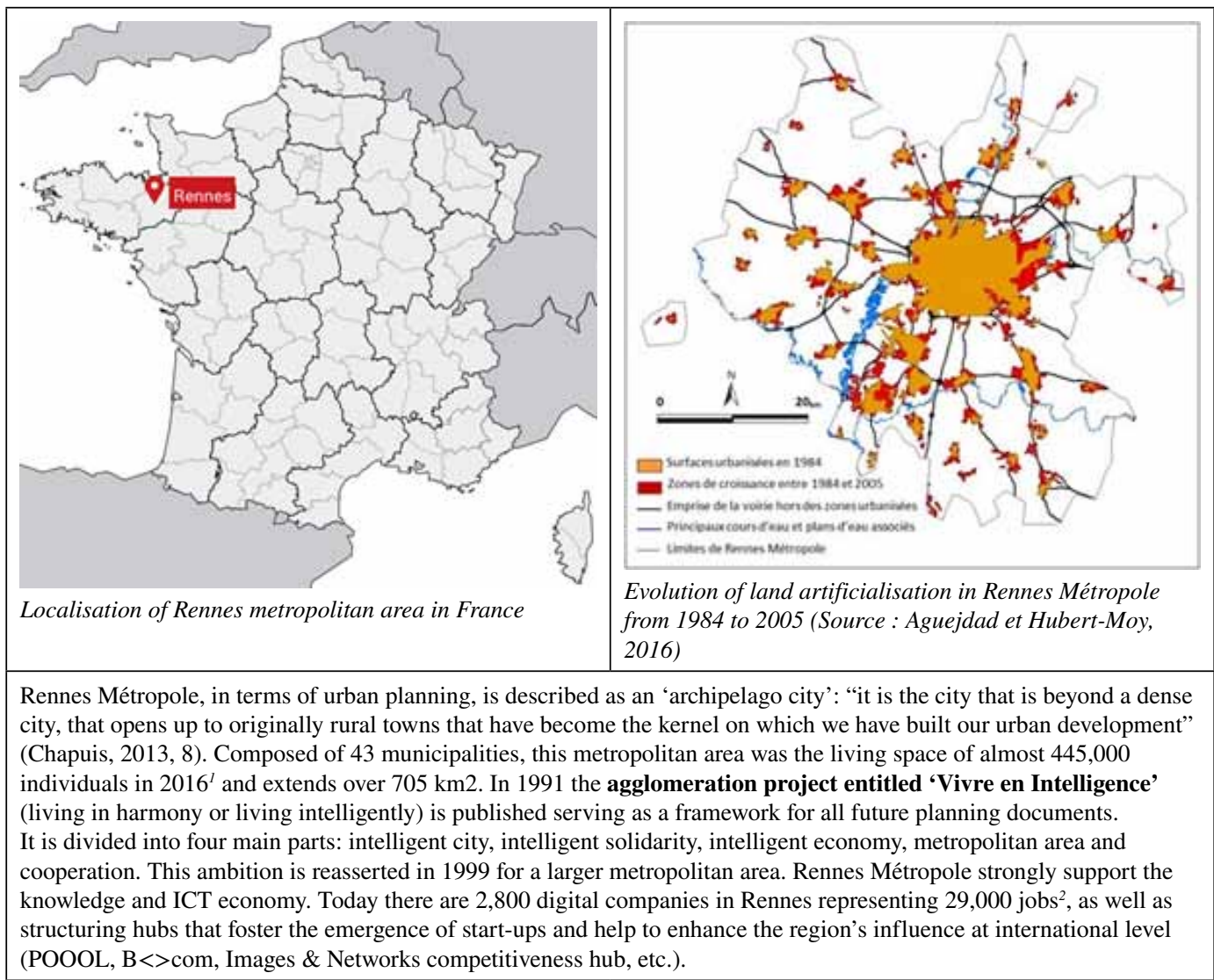

'Source: INSEE (for further information:https://www.insee.fr/fr/statistiques/1405599?geo=EPCl-243500139)

${ }^{2}$ Source: Rennes Métropole (for further information:https://metropole.rennes.fr/rennes-metropole-numerique, consulted in September 2019)

\subsection{Seeking Players From Rennes Smart City: The SmartRennes Project}

SmartRennes project forms part of a national research approach, supported by $\mathrm{PUCA}^{7}$ and two French ministries, which compares different French metropolitan areas. The challenge of the research is to understand what forms the urban innovations take from both the viewpoint of governance and that of transforming the organisations in charge of their design and implementation. The SmartRennes research answers these two objectives by proposing a historic study, a qualitative approach of stakeholders and an organisational study. The historical approach makes it possible to place the emergence of the smart city in its local context and to show how this initiative is built by strategic choices or not. The qualitative approach aims to question the various stakeholders' appropriations of the notion of smart city. Finally, the organizational analysis shows that the Rennes' smart city initiative fits into structures that are already in place without overhauling them. By a monographic perspective focused on smart city policy we intent to demonstrate that the implementation of smart city model at local level needs comprehensive approach of public players actions, partnerships and political decisions (Courmont et Le Galès, 2019).

Thanks to an action research agreement between Rennes Métropole and the project team, the study protocol is based on 3 interwoven methods: 1/qualitative interviews, 2/observation of events and meetings, and 3/exchanges with the actors involved on the results of the research. 


\begin{tabular}{|c|}
\hline Steering \\
\hline Smart City Division \\
Smaty Project Steering Committee \\
\hline
\end{tabular}

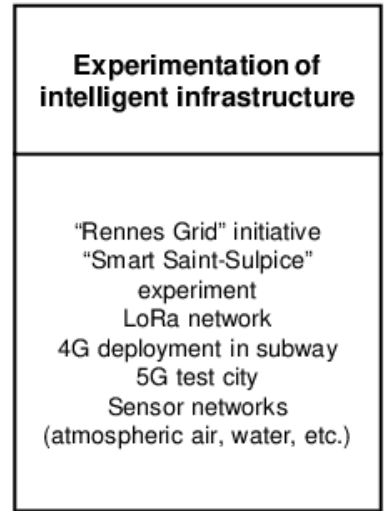

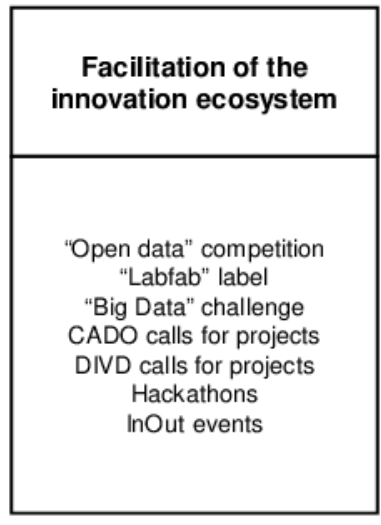

Source: SMARTRENNES survey Created by: Marie-Anaïs Le Breton, for SMARTRENNES

1. The interview grid is divided into three stages:

- Stage one: the persons interviewed produce a diagram of the stakeholders (sociogram) with whom they are involved in dealing with innovation or projects identified as relevant to the smart city.

- Stage two aims to reconsider the key moments of the smart city initiative. Here we question people on their involvement in different projects related to smart city, their implementation and the driving forces and impediments identified.

- Stage three makes it possible to tackle the issue of the near future: What projects for tomorrow? What difficulties could arise?

Over the period from December 2018 to September 2019, we carried out 34 interviews (Figure 2) with some of the stakeholders involved in the Rennes smart city. The sample is constructed on the basis of a list of stakeholders explicitly involved in the implementation of the Metropolitan Public Data Service and 3D Experiencity-Virtual Rennes platform. This is why the results must be put into perspective since they only concern the actors involved in this particular projects and not all stakeholders. However, this choice is justified by our research objective. We want to survey the actors officially involved in the governance of the smart city in order to describe the parameters of its conduct. Our methodological design did not aim to assess for example public reception of the Rennes' smart city initiative, but to understand its implementation. 


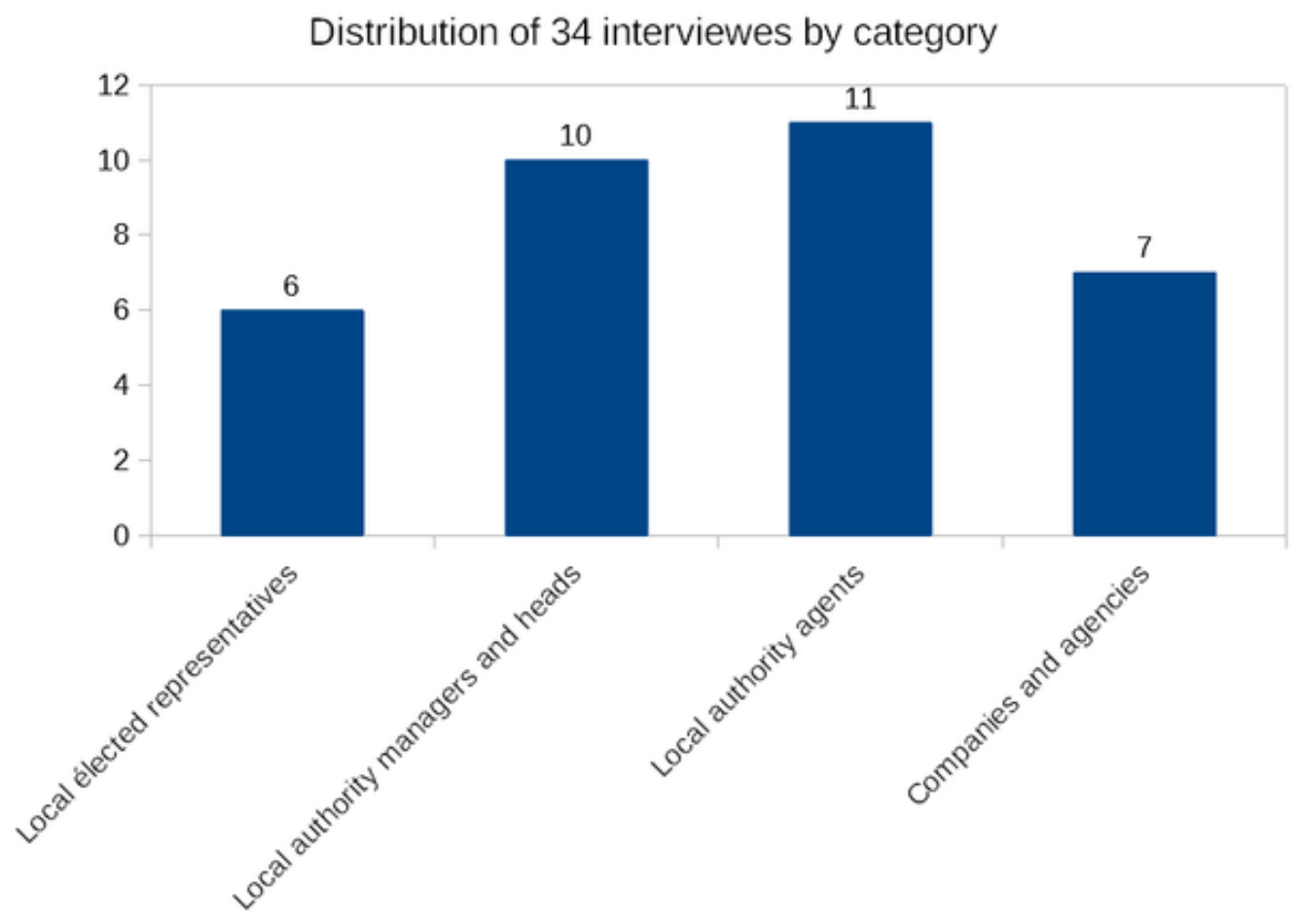

2. The agreement also allowed us to access to various meetings and events, both internally and for the public, which enriched our knowledge of the field (Figure 3).

3. We also organised a Study Day on 24 June 2019 devoted to smart city governance, which brought together both researchers and professional players. Four case studies were presented ${ }^{8}$

Figure 3. List of meetings and workshops observed by research team

\begin{tabular}{|l|l|}
\hline $27 / 11 / 2018$ & $2^{\text {nd }}$ Metropolitan Public Data Service encounter \\
\hline $21 / 02 / 2019$ & Steering Committee of 3D Experiencity-Virtual Rennes platform \\
\hline $28 / 02 / 2019$ & Digital Technology and Data Uses encounter \\
\hline $28 / 03 / 2019$ & $2^{\text {nd }}$ InOut meeting (smart mobility) \\
\hline $23 / 05 / 2019$ & $3^{\text {rd }}$ Metropolitan Public Data Service encounter \\
\hline $15 / 07 / 2019$ & Training on 3D Experiencity-Virtual Rennes platform \\
\hline $02 / 09 / 2019$ & Data sharing meeting \\
\hline $18 / 12 / 2019$ & $4^{\text {th }}$ Metropolitan Public Data Service encounter \\
\hline
\end{tabular}


(Rennes, Lyon, Paris and Nantes), with the common denominator of calling into question the governance of data, the experimentations linked to the smart city policy, as well as the support and moderation of the mechanisms proposed by public players. Exchanges made it possible to deepen the importance of public control, the integration of citizens and the place of digital companies in the implementation of a smart city, also calling into question the emergence of a 'French-style' model of smart city.

\subsection{Mixed Methods For Representing The Diversity of Rennes Smart City Initiative}

\section{The Structure of Action}

Interviews, encounters and exchanges (during the study day) allowed us to produce the following diagram (Figure 4), which draws up a list of all the actions that form part of the 'Rennes-style' smart city since 2010, according to the persons interviewed:

While the appearance of open data policy dates back to the first decade of the 2000s, the arrival

Figure 4. Actions and measures of Rennes smart city policy between 2010 and 2020

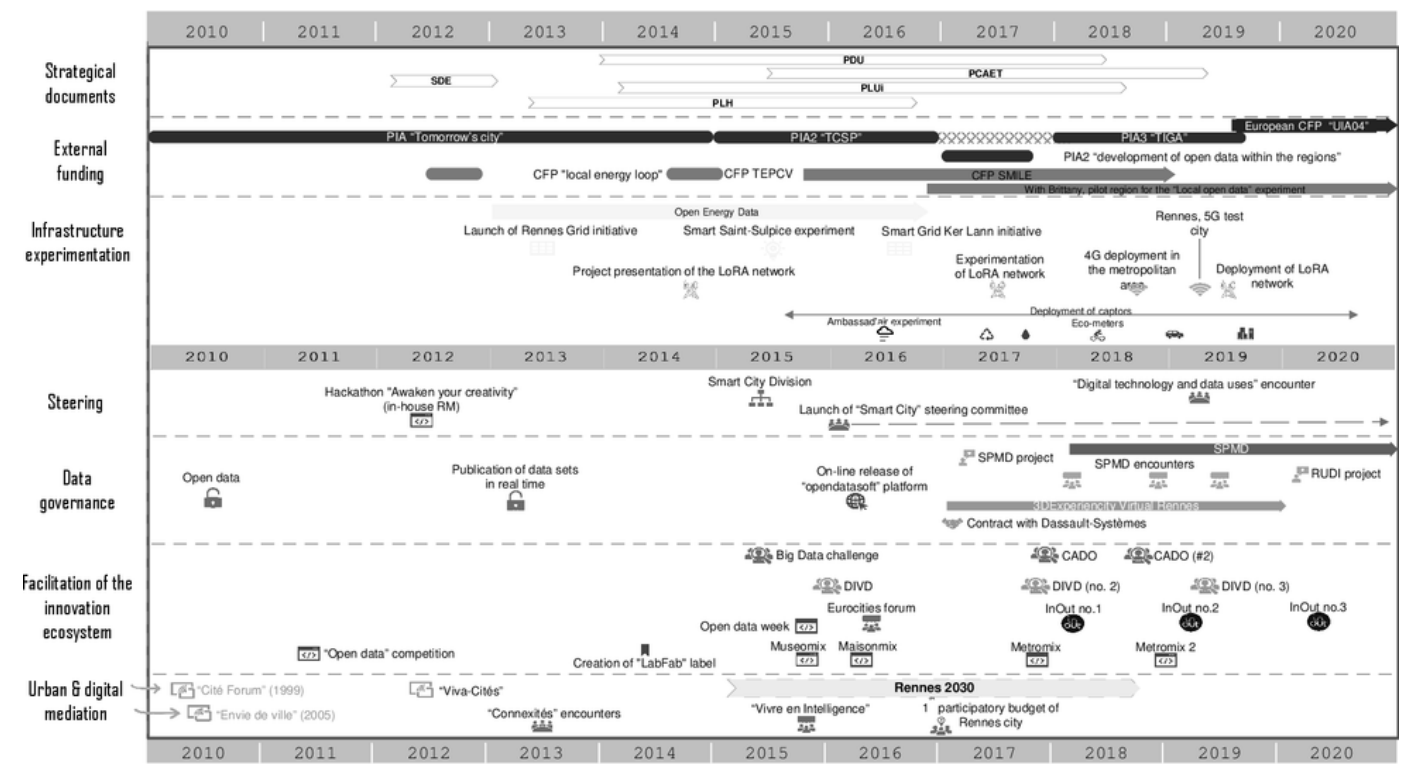

of the smart city delegation in 2015 marked a turning point by ensuring that a mission focused on implementing the process became part of the organisational structure (steering). The first 'smart city' steering committee, driven by a strong will for a cross-cutting approach, therefore identified the different actions that were part of the smart city initiative. This steering committee links projects in the areas of infrastructure, data governance, support for innovation ecosystem and urban mediation. While the projects in the field are supported by the various departments of Rennes Métropole, the steering committee shall ensure they pursue a common purpose (efficiency, inclusion, equality). This objective involves coordinating action and telling the story of the Smart city's initiative. This type of representation makes it possible not only to analyse the progressive construction of the smart city initiative, but also its interactions with various external opportunities (Strategic documents, external funding). We thus show how smart city policy has been under construction for more than 10 years (cf. 3.1). 


\section{Analysing "Visions" of The Smart City}

As part of the discourse analysis of the interviews, we guided our reflections towards the values and visions of the smart city, shared or not by the stakeholders interviewed. The purpose of this analysis is to determine the possible association of stakeholders around a collective imagination, or, on the contrary, possible diverging viewpoints. Highlighting values and their dissemination informs us of the challenges and issues of the political conduct of the smart city.

During the interviews, open questions concerning the objective associated with the smart city and definitions or expectations concerning Rennes smart city allowed us to focus our research on a lexical analysis, by studying redundancies in verbatim themes, symbols, comments or judgments. The main smart city's themes broached during the interviews were environmental, social, urban, economic and political one. We then established a distinction between an expression that referred to a rather positive (expectation) or negative vision (dissatisfaction) of the themes.

We obtained a global view of the perceptions associated with the challenges raised by the smart city (Figure 5). The analysis highlights the representations differentiated by groups of players, depending on their sector of intervention or their role.

Figure 5. General model of themes related to Smart City in the discourses of interviewees

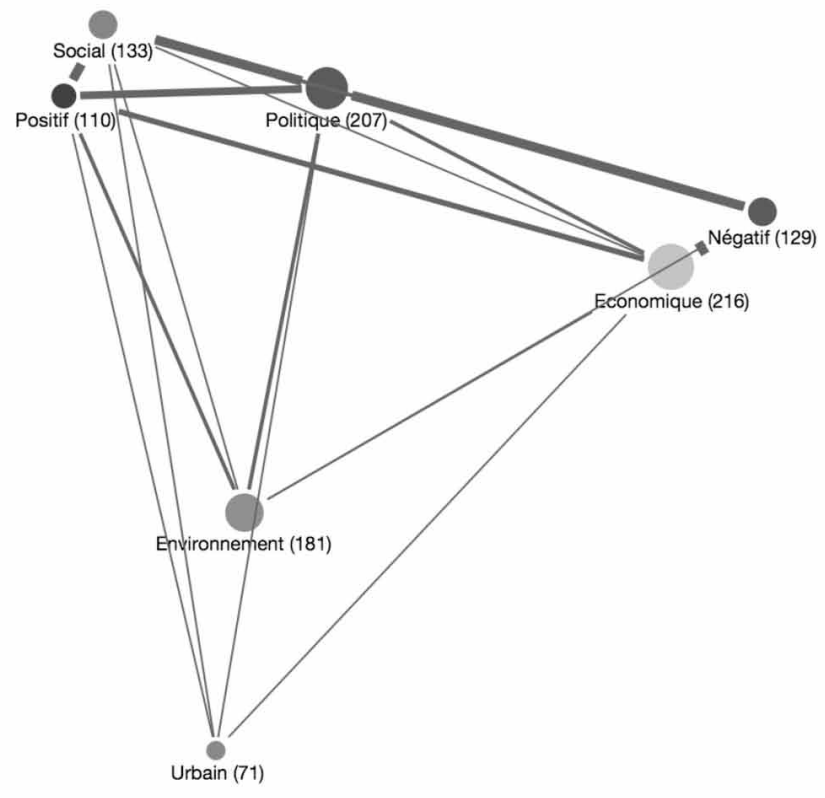

In terms of visualisation, we obtain a general model of these themes, represented by nodes and links. The nodes represent the theme - environmental, social, economic, political, urban -, and are either positive or negatively evaluated. The size of the nodes corresponds to the occurrence in the discourses collected, their relative position indicates if they are close or even superimposed in the discourse. Furthermore, the links and their thickness indicate if the stakes are associated with each 
other in terms of references (The absence of a link on the graph indicates the absence of an association in the discourse).

We can see for example in this general model (Figure 5) that the political theme seems to be at the centre of the considerations of the players interviewed. This theme is also associated with negative or positive opinions, the players therefore seem dubious or expectant concerning political support, a vision or a process initiated by the political player. The political theme for example refers to expectations in terms of citizen consultation, the involvement of ecosystem players by the public player, and the role of the latter in a smart city initiative. Furthermore, the social theme, close to that of positive opinion, seems to enjoy consensus concerning the need to build an inclusive smart city but is also associated with a negative viewpoint, in particular in terms of shortcomings perceived for the public player and a 'lack of competence' concerning social actions. The economic node shows an obvious alignment with negative opinion, mainly concerning the risks linked to public data and their reuse by private players. Lastly, the environmental and urban nodes seem to be far away, even though they are part of the stakes of the smart city. So, there seems to be consensus on the fact that the smart city must be sustainable, and for this, it must provide appropriate urban amenities. We will return to the detailed analysis later (cf. 3.2).

\section{Network Analysis}

The sociogram exercise (stage one of the interview) has allowed to highlight the engaged players and their relations at a given time, and to question the hypothesis of the development of a new 'urban regime' with the smart city (Pinson, 2010; Courmont \& Le Galès, 2019). The creation of a graph based on the survey of all the players cited during the 34 interviews, as well as the links that bind them, pursues our goal of network analysis. The aggregation of these data and the work carried out based on an algorithm (Force Atlas 2 - on Gephi), allows us to question one of the possible visualisations of current governance of Rennes smart city. This visualisation of the networks does not aim to be exhaustive, but rather to question the coordination of the smart city initiative in Rennes (Figure 6).

Evaluating the involvement of the players mentioned during the interviews is carried out in the following manner: the closer the player (symbolised by a round node) is to the centre of the network, the more he aggregates links with others; the wider the diameter of the node, the more the player is cited by his partners. In the interest of anonymity, when agents or elected representatives were mentioned by name, they were placed in their corresponding category. The public player that is Rennes Métropole was precisely identified wherever possible. We chose to regroup the players cited in relation to their key roles of intervention as well as their main policy directions. A detailed analysis of these data will be dealt with below (cf. 3.3).

\section{STRUCTURE, COLLECTIVE IMAGINATION AND GOVERNANCE OF THE RENNES SMART CITY INITIATIVE}

\subsection{Structuring Tools: Controlling, Using and Sharing Urban Data}

Implementing Rennes smart city is through the development of several data platforms that takes many forms. Since the arrival of the new municipal team in 2014, lots of data-based partnerships have taken shape. One focuses on 'business uses' of urban data and the Geographic Information System direction initiative for enhancing digitalisation and re-engineering of business process (3D EXPERIENCity®-Virtual Rennes platform). The other concerns the upgrading of open data portal and the redesign and further development of Rennes Métropole data policy (Metropolitan Public data Service and Rennes' urban data interface). This open data portal is supported by the communication direction. As an in-between objective we observe the development of the fab city and the deployment of a local low frequency network and local produced sensors, supported by the digital innovation 


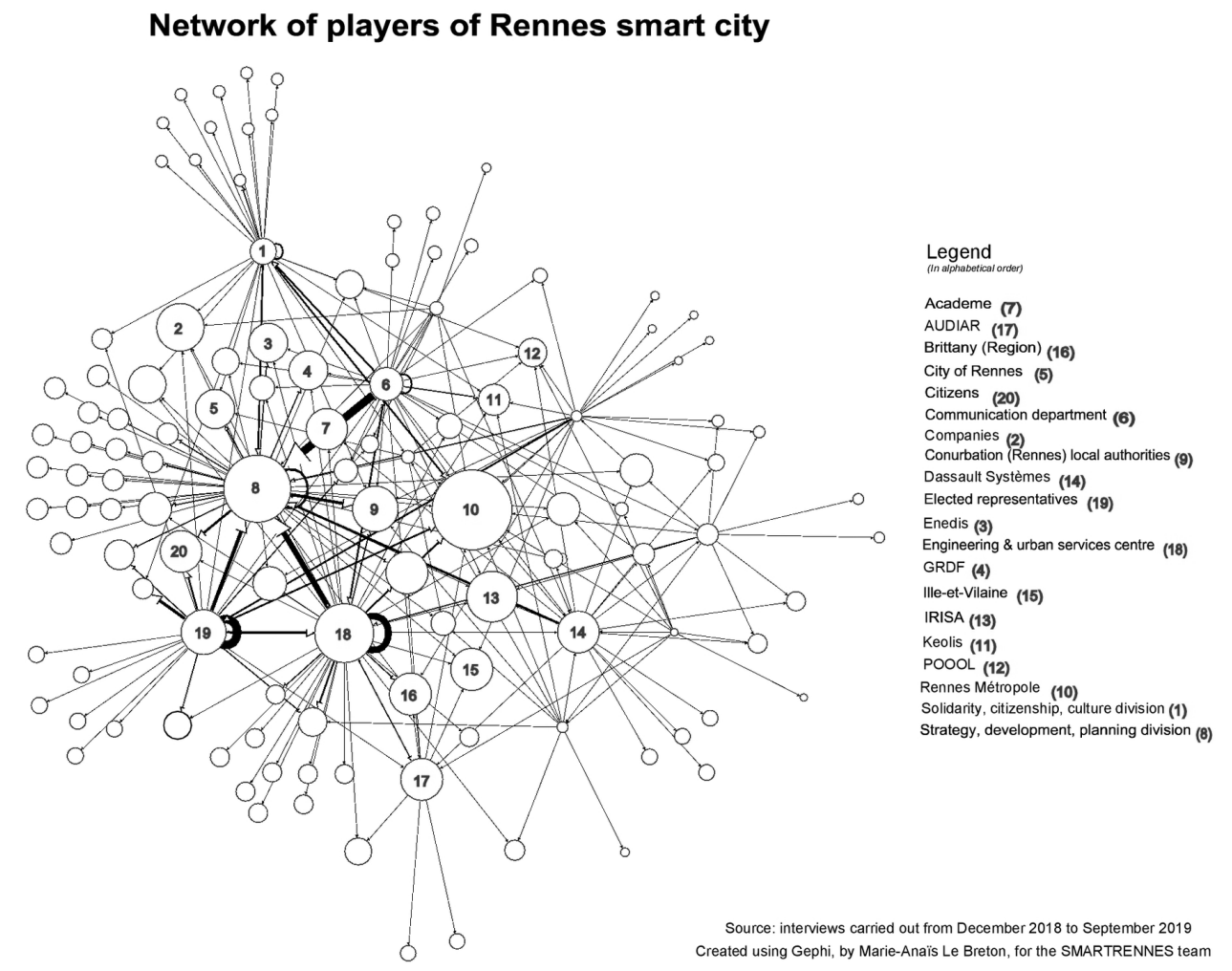

service. In this part, we return to the steering and governance instruments of the data identified using our surveys (Figure 7).

The project of a digital platform for 'business uses' of urban data and on the design of urban projects' process are part of a long experimentation (since 1999). The partnership initially involved a Rennes-based company (Archividéo) specialised in 3D territorial modelling, in order to meet the visualisation needs of various departments of local authority (internal or external) in charge of urban projects. Purchased by Dassault Systèmes in 2013, this 3D urban modelling technology includes a platform of software solutions proposed to cities by a software 'giant' for industry and engineering. The process takes the form of a local demonstrator, who, in Rennes, is supported by the GIS division, in partnership with the DSI (computer system department) and the smart city division. Rennes Métropole and Dassault Systèmes jointly respond to calls for proposals by the French State and have been developing use cases of the 3D EXPERIENCity®-Virtual Rennes platform since 2017. Within the framework of this demonstrator, innovation governance has been established based, on the one hand, on a call for proposals for SMEs from the local digital sector (six calls for experimentation have been launched) and on the other hand inter-department working groups that relay needs upstream in terms of use of the platform. This experimentation has led to cooperations in the case of Rennes 2030 consultation (urban mediation about the metropolitan urban strategy). A block seems to be missing here, that of usage. In fact, very few people in Rennes Métropole use the platform's services despite the working groups. A lot of energy is spent creating the 'use cases' that help to encourage various uses. To date, 3D EXPERIENCity ${ }^{\circledR}$-Virtual Rennes is not governed by a public contract, but for the past four years has been under experimental status, even though a partnership contract has been signed 
Figure 7. Diagram of the main objectives of smart city initiative in Rennes

\begin{tabular}{|c|c|c|c|c|c|c|c|}
\hline Objectives & Projects & 2015 & 2016 & 2017 & 2018 & 2019 & 2020 \\
\hline \multirow{4}{*}{$\begin{array}{l}\text { Development } \\
\text { of a public- } \\
\text { private smart } \\
\text { city }\end{array}$} & \multirow{2}{*}{$\begin{array}{l}\text { Urban Mediation } \\
\text { using digital } \\
\text { devices }\end{array}$} & \multicolumn{4}{|c|}{$\begin{array}{l}\text { Rennes } 2030 \text { - citizen consultation and public } \\
\text { information about metropolitan urban strategy }\end{array}$} & \multirow[b]{2}{*}{$\begin{array}{l}\text { Participator } \\
\text { y budget } \# 3\end{array}$} & \\
\hline & & & & $\begin{array}{c}\text { Participatory } \\
\text { budget } \# 1\end{array}$ & \begin{tabular}{|c|} 
Participatory \\
budget $\# 2$
\end{tabular} & & \\
\hline & $\begin{array}{l}\text { Supporting the } \\
\text { Innovation } \\
\text { Ecosystem }\end{array}$ & \multicolumn{6}{|c|}{$\begin{array}{l}\text { CADO, DIVD and InOut: call for small and big companies for developing } \\
\text { innovative services (customers services, softwares, mobility) }\end{array}$} \\
\hline & $\begin{array}{l}\text { Business Process } \\
\text { Re-engineering }\end{array}$ & & \multicolumn{4}{|c|}{$\begin{array}{l}\text { Contract with Dassault-Systemes: experimentation } \\
\text { of 3D Experiencity-Virtual Rennes platform }\end{array}$} & $\begin{array}{c}\text { End of } \\
\text { contract }\end{array}$ \\
\hline \multirow[b]{2}{*}{$\begin{array}{l}\text { Development } \\
\text { of "fab city" }\end{array}$} & Digital events & \multicolumn{6}{|c|}{ Annual 'hackathon' for developers: museomix, metromix, maisonmix... } \\
\hline & $\begin{array}{l}\text { Projects from 'Fab } \\
\text { lab' network }\end{array}$ & & $\begin{array}{l}\text { Air quality } \\
\text { sensors }\end{array}$ & $\begin{array}{l}\text { Low } \\
\text { frequency } \\
\text { network }\end{array}$ & $\begin{array}{l}\text { Deployment } \\
\text { (mobility, ene }\end{array}$ & $\begin{array}{l}\text { of communic } \\
\text { ergy...) }\end{array}$ & cative sensors \\
\hline \multirow{3}{*}{$\begin{array}{l}\text { Development } \\
\text { of public data } \\
\text { service }\end{array}$} & $\begin{array}{l}\text { Upgrading of open } \\
\text { data portal }\end{array}$ & & \multicolumn{5}{|c|}{ Online release of Opendatasoft 8 platform (data sets in real time) } \\
\hline & $\begin{array}{l}\text { Metropolitan Public } \\
\text { Service of data }\end{array}$ & \multicolumn{2}{|c|}{ Search for funding } & \multicolumn{3}{|c|}{$\begin{array}{l}\text { Annual encounters about govemance } \\
\text { of data, stakeholders coordination }\end{array}$} & Report \\
\hline & $\begin{array}{l}\text { Rennes urban data } \\
\text { interface }\end{array}$ & & & & \multicolumn{2}{|c|}{ Search for funding } & $\begin{array}{l}\text { Launch of a } \\
\text { new platform }\end{array}$ \\
\hline \multirow{2}{*}{ Steering } & Smart city division & $\begin{array}{l}\text { Project } \\
\text { manager }\end{array}$ & & $\begin{array}{l}\text { New } \\
\text { collaborator }\end{array}$ & & & $\begin{array}{c}2 \text { New } \\
\text { collaborators }\end{array}$ \\
\hline & $\begin{array}{l}\text { Organisational } \\
\text { means }\end{array}$ & & \multicolumn{5}{|c|}{$\begin{array}{l}\text { Monthly steering committee (with elected representatives), } \\
\text { workshops, working groups, intemal events }\end{array}$} \\
\hline
\end{tabular}

for a 3-year period (ending in 2020). This first example is a classic case of the implementation of the smart city in large global metropolitan areas: an almost 'free' service provided by an industrialist seeking to show the value of his product by experimenting with public players. In our case the collaboration was interrupted in 2020.

The project of Metropolitan Public Service for Data (SPMD) was launched in 2017 after it obtained State funding as part of the Etatlab process. The challenge is to prefigure, with major partners from the line of business (Enedis, GRDF, ALEC, Eau du bassin rennais for energy data, Keolis for public transport data, CCAS and APRAS for social data, etc.), a policy of data sharing beyond the opening up of public data already underway. For two years, the project was aimed at prefiguring for the role of a metropolitan public service for data at territory level. The challenges are numerous: improving public policies, supporting companies innovation and intensifying the use of data by urban users (services). Since the open data portal was launched in 2010, there have been numerous initiatives favoring the use of data for urban innovation (hackathon, Fab Lab, low frequency networks and local produced sensors). But today they require coherent public steering that reconciles public data but also those from private players ready to share their data. The prefiguration approach we have observed shows the need to unify a certain number of projects that co-existed up until then. In this case, the smart city points to the major challenge of piloting the ongoing projects, the public player acting as organiser of the process and guarantor of its values. In 2019, the SPMD project obtained major funding from the European Union allowing it to move to the development stage of a public-private data sharing platform (Rennes Urban Data Interface).

Both approaches involve major transformations, both in the structuring of players and in the formulation of a smart city model. But today, both models co-exist: on the one hand that of the centralisation of data and their uses in a closed platform aimed at improving the local authority's 
performance (private platform, centred on process re-engineering). On the other, that of an open data platform that does not influence future uses or the value that will be created. Both models co-exist today in the implementation of Rennes smart city. It will be interesting to observe in the future if one takes precedence over the other. This first result concerning the complex structuring of the smart city initiative in Rennes leads us now to question the diversity of the representations and expectations of our interviewees.

\subsection{Conduct of Rennes Smart City: 'Shattered Collective Imagination'}

The discourse analysis of the interviews makes it possible to compare the representations of the different types of players, and to report on a 'shattered collective imagination' of the smart city. Therefore the sample were ranked by type of player. We thus obtain a general model and four specific models: 1/the elected representatives, 2/the managers and heads of departments or divisions, 3/ Local authority's agents and 4/companies. By comparing the models with each other, or in relation to the general model, we can show converging and diverging viewpoints concerning the smart city underway in Rennes.

The model of elected representatives' imagination of the smart city (Figure 8) is similar to general model. We can thus advance the idea that this imagination enjoys strong political support allowing the harmonised dissemination of the smart city approach by the elected representatives of Rennes Métropole towards all players in the metropolitan region.

Figure 8. Issues and values associated with the smart city: the case of elected representatives

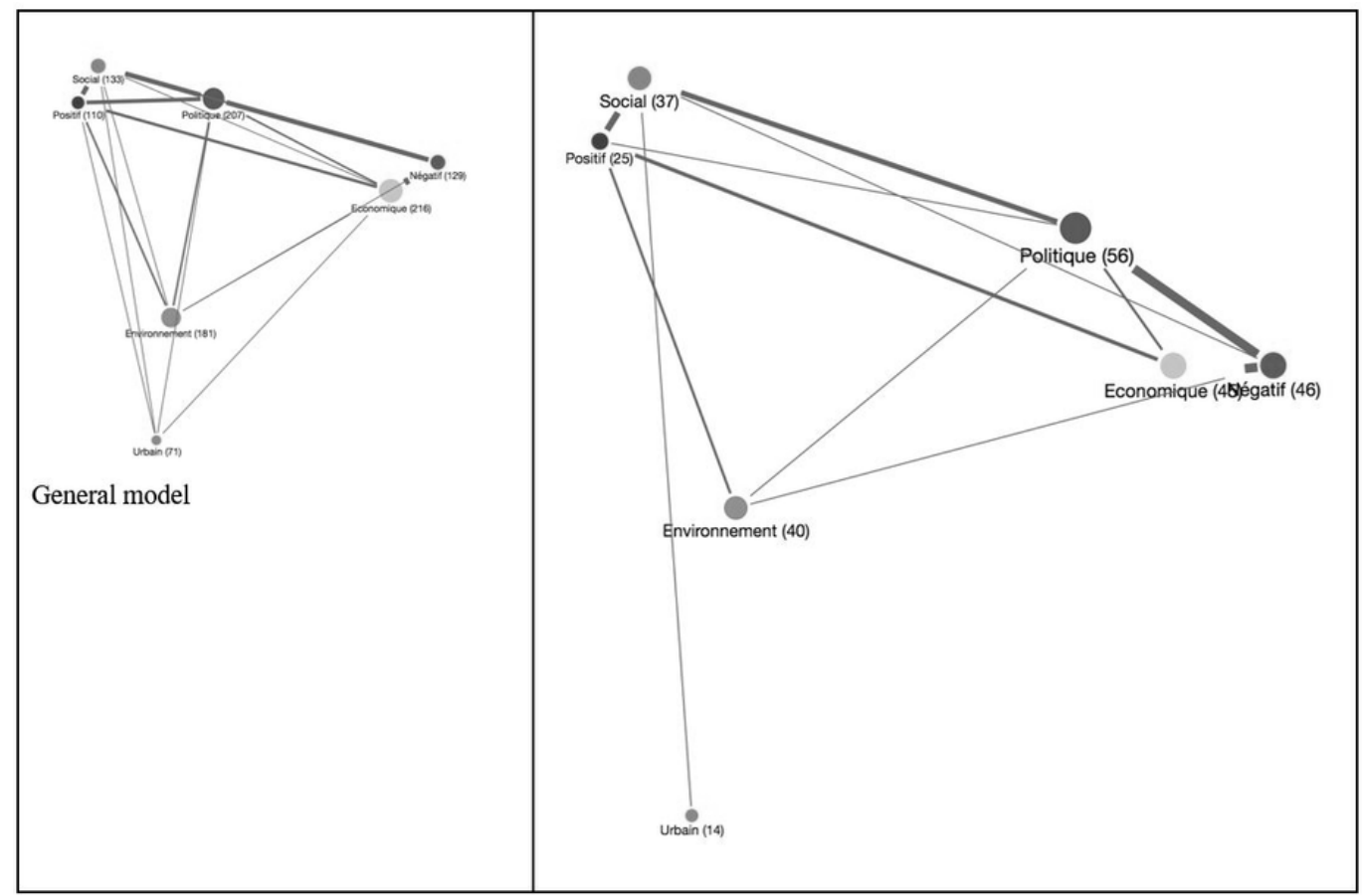

Several elements of this model deserve to be examined. First of all, the position of the political dimension in the centre, which is subject to discussions between the social, economic, and the negative 
pole. These themes therefore seem to be at the centre of smart city issues for elected representatives, or they at least require cross-cutting and joint reflection on these subjects on their part.

In addition, the widely cited economic dimension is close to the negative pole. This proximity can in particular be explained by distrust concerning the smart city term itself, and its definition is likely to refer uniquely to a term from the economic world. As we saw in the literature review, this distrust can be explained by the fact that the smart city concept is a notion that was primarily disseminated by the economic players with the purpose of winning new markets. It was then taken over by the political world, without theorisation or hindsight. Elected representatives interviewed today lack feedback on this smart city. They point out the risk for public players to believe too easily in promises made by companies who propose a 'control tower' capable of managing and anticipating an ideal city, but above all one that is techno-centred.

On the other hand, for the elected representatives interviewed, the economic aspect associated with the smart city resembles a rather negative vision of its effect on politics. Public players, faced with Big Five, need to pay a certain 'price' for their freedom, to preserve it and to legitimise their intervention.

In this diagram (Figure 9), the environmental dimension is less cited, but globally viewed in a positive manner by managers and heads of divisions. This theme is also linked to all the other themes, it therefore seems to be a vital element of the smart city and a goal to be reached.

Figure 9. Issues and values associated with the smart city: the case of managers or heads of departments and divisions

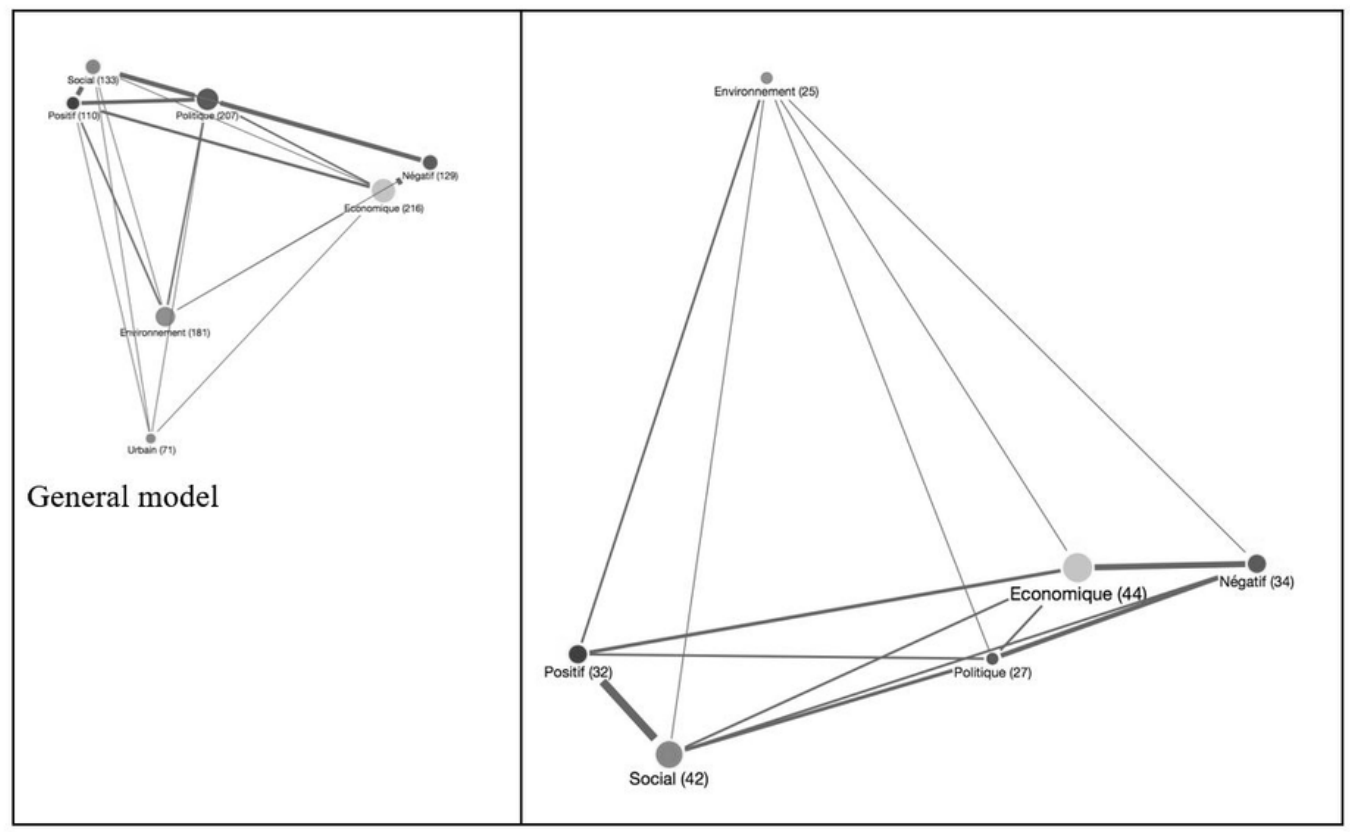

The environmental dimension in the smart city therefore seems to enjoy consensus for this category of stakeholder. For example, the positive value of the smart city's environmental dimension is linked to a vision of a 'solution' provided for the challenges of sustainable development. The smart city could help meet the challenges of urban resilience. These players underline the link between the environmental, economic, social and political dimensions. The smart city is strongly linked to the 
co-construction of a sustainable city and must involve the pursuit of the common good and support by public policies in its approach.

At the same time, considerations expressed about digital technology and its use convey a more negative view of the smart city which may not allow sustainability to be reached. These players are aware of the paradoxes in which they operate.

Thus, and as we have seen earlier in the article, a smart city as a techno-centred and digitally augmented city does not seem desirable or at least not sufficient, if it does not involve all its players in the goal of innovative handling of the territorial challenges, especially environmental.

It is important to put this model (Figure 10) into perspective considering the limited number of agents interviewed. In fact, we interviewed the agents cited as participating in the smart city initiative, especially through projects. Their participation is high and is linked to the Rennes Métropole organigram, in other terms, it is linked to the departments involved in the Rennes smart city initiative (see network analysis below).

Figure 10. Issues and values associated with the smart city: the case of local authority agents

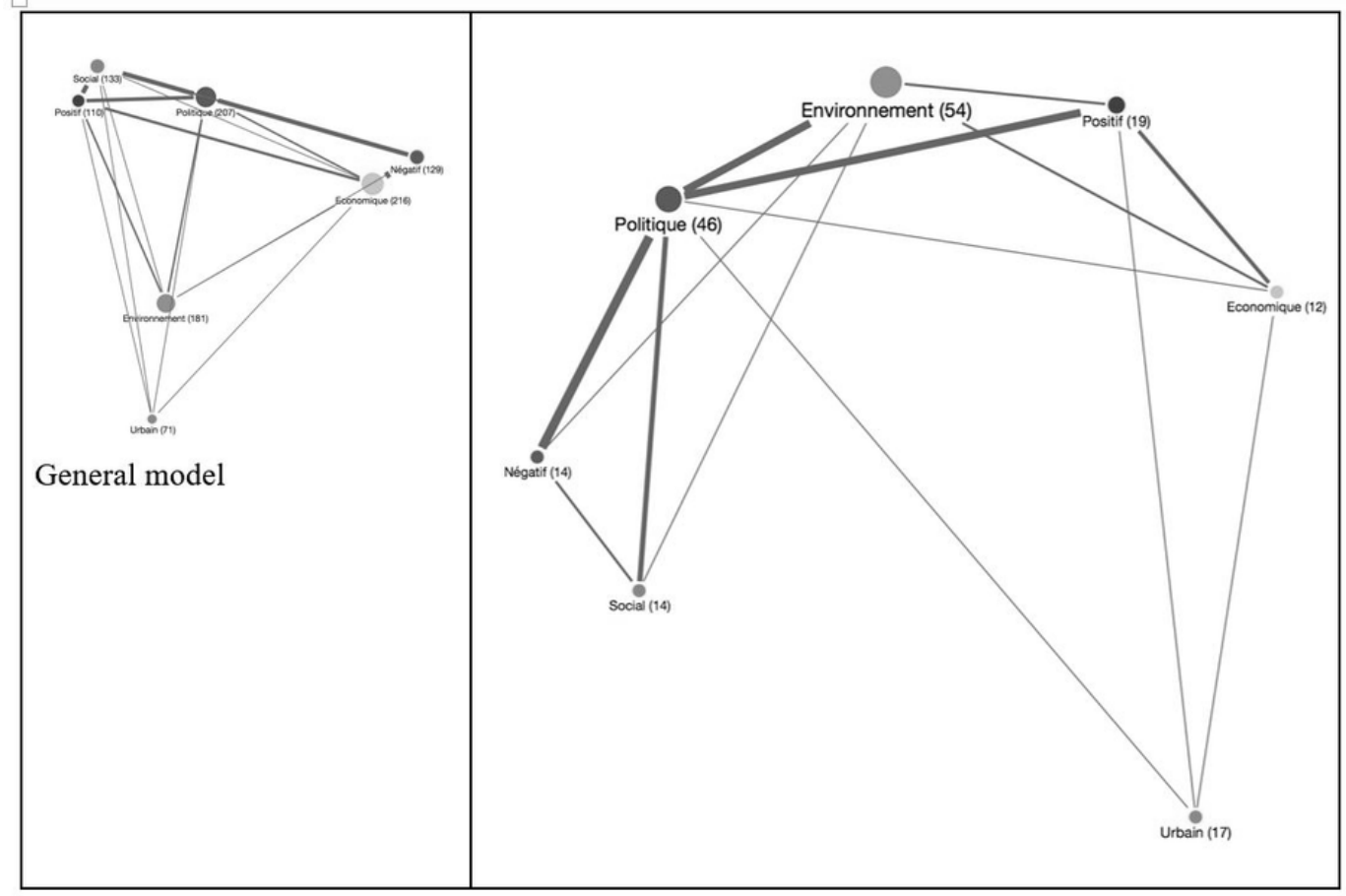

We can therefore see that when modelling the imagination of the agents interviewed, the key dimension of the environment is highlighted: Rennes smart city must be sustainable and for this, the link between the environmental and political themes must be thick. In fact, the political dimension of the smart city could allow agents to provide coherent guidance to the construction of the city, and to help change behaviour through information, education, etc. Furthermore, giving a strong political dimension to Rennes smart city, for agents, means continuing to be the trusted third party and reassuring citizens in the digital transition underway. Political support shall allow them to be the guarantors of the use of personal data, considered as usefull for buildind a more sustainable city. The political value of Rennes smart city is also, for agents, that of being caring and inclusive in order to 
promote and drive citizen-based dynamics. The environmental, economic, political themes are also linked together, expressing their waiting for a well coordinated ecosystem.

However, the political theme also concentrates negative views, in particular linked to the question of legitimacy and representativeness, as well as the issue of competence cited by agents, to manage communities of citizens. Without consultation, the agents are aware of a "risk of doing unnecessary or even negative things" or things that are misunderstood by citizens. Collecting citizen's viewpoints becomes more difficult and complex, due to the multiplicity of digital means. For the interviewed Public players are therefore no longer the favoured intermediary to report on citizen's opinions they fear that it will be worst in the future.

What differs in this model of companies interviewed (Figure 11) is the economic dimension becoming a key element in discourse, which is extremely connected to the other themes and associated firstly with a negative evaluation. It in fact seems surprising that companies, players of the economic sphere, identify risks and impediments to the economic dimension of the smart city. The players interviewed therefore identified the gap between business interests and those of public players and of the community. Companies are aware of creating services that are not always a response to citizens' needs. This could be offset by better access to public procurement which they deem difficult today, especially in terms of temporality and decision-making.

Figure 11. Issues and values associated with the smart city: the case of companies

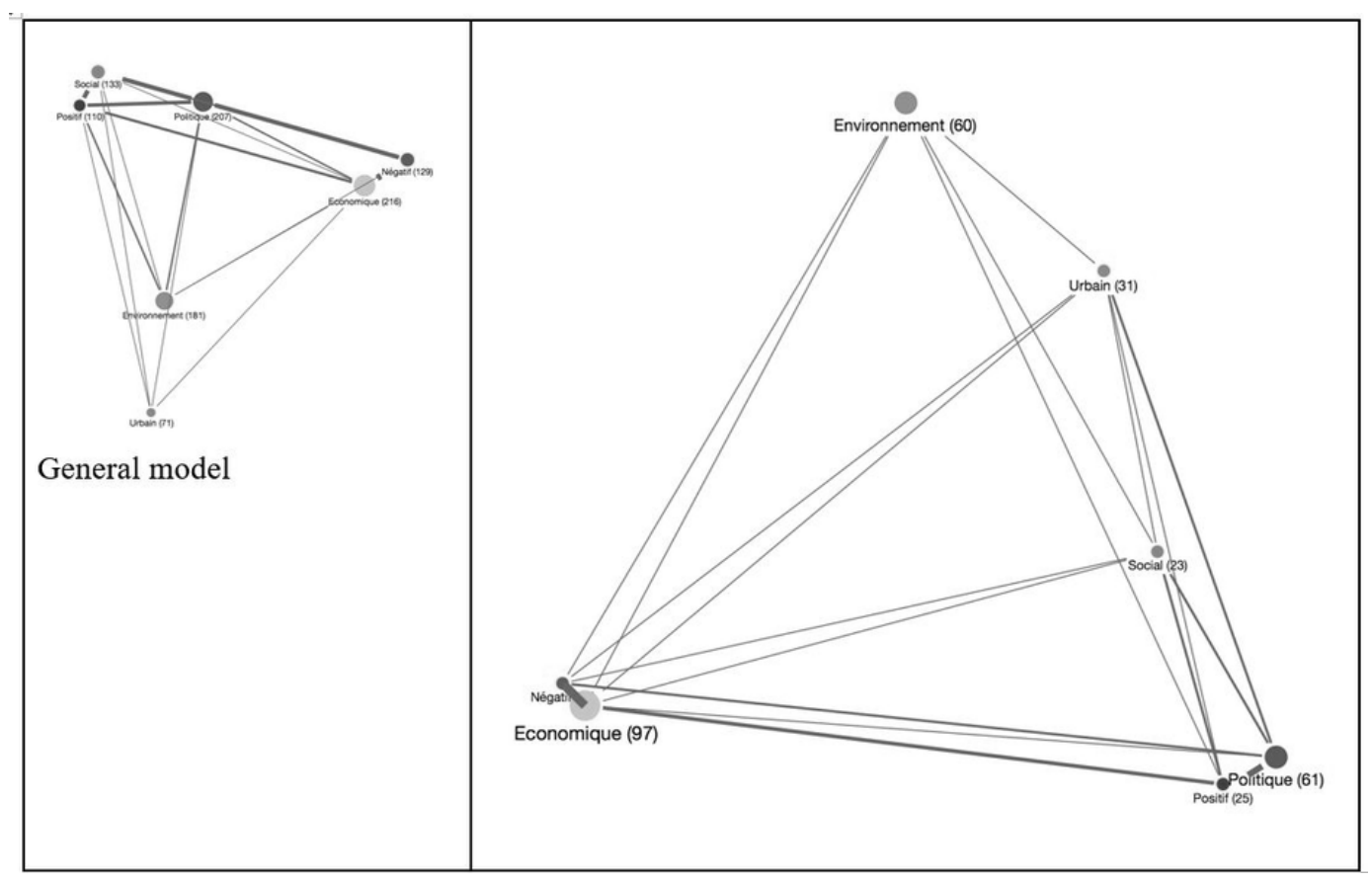

The negative evaluation of the economic dimension in the smart city is also linked to the idea that they have of the term 'smart city', as being a 'smoke screen' whose definition highlights the goal of market rather than that of innovation.

However, the political dimension is expressed more positively here, as a reference to the construction of a collective dynamic, the possibility of sharing information and data that allows and facilitates research in the collective interest. The political dimension is seen positively given the risks 
of an economic-oriented smart city. The view of economic players indicates their expectations in terms of public governance of innovation. In fact, although economic players want data and information to be shared, they are aware of the risks of domination of individual interest over the collective interest. It is therefore important to ensure legal regulation by the public player and not by the private player, so that public control promotes the security of citizens and their data.

Despite these diverse players' views of Rennes smart city, there is a certain amount of agreement. For example, all stakes are cited or used by the players interviewed and it seems therefore, that the message of Rennes Métropole is understood, even if it is translated differently.

\subsection{Governance of Rennes Smart City: Players and Networks}

At Rennes Métropole, the smart city is an approach involving a large variety of players and types of connection: support for business development, mentoring, enabling visibility, conventions, partnerships, etc. The players, or groups of players, who have more links than the others are Rennes Métropole (cited as an institution), the 'strategy, development and planning' and 'engineering and urban service' divisions, as well as the 'elected representatives' (Figure 12). This fragmented representation of the public actor is indicative of a project-based structuring (as shown above). We can also note a form of tension or even exclusion of certain directions that are nevertheless carrying important initiatives with their own network (Communication department or Social, citizenship and culture division).

Figure 12. Categorisation of the player network of Rennes Smart City

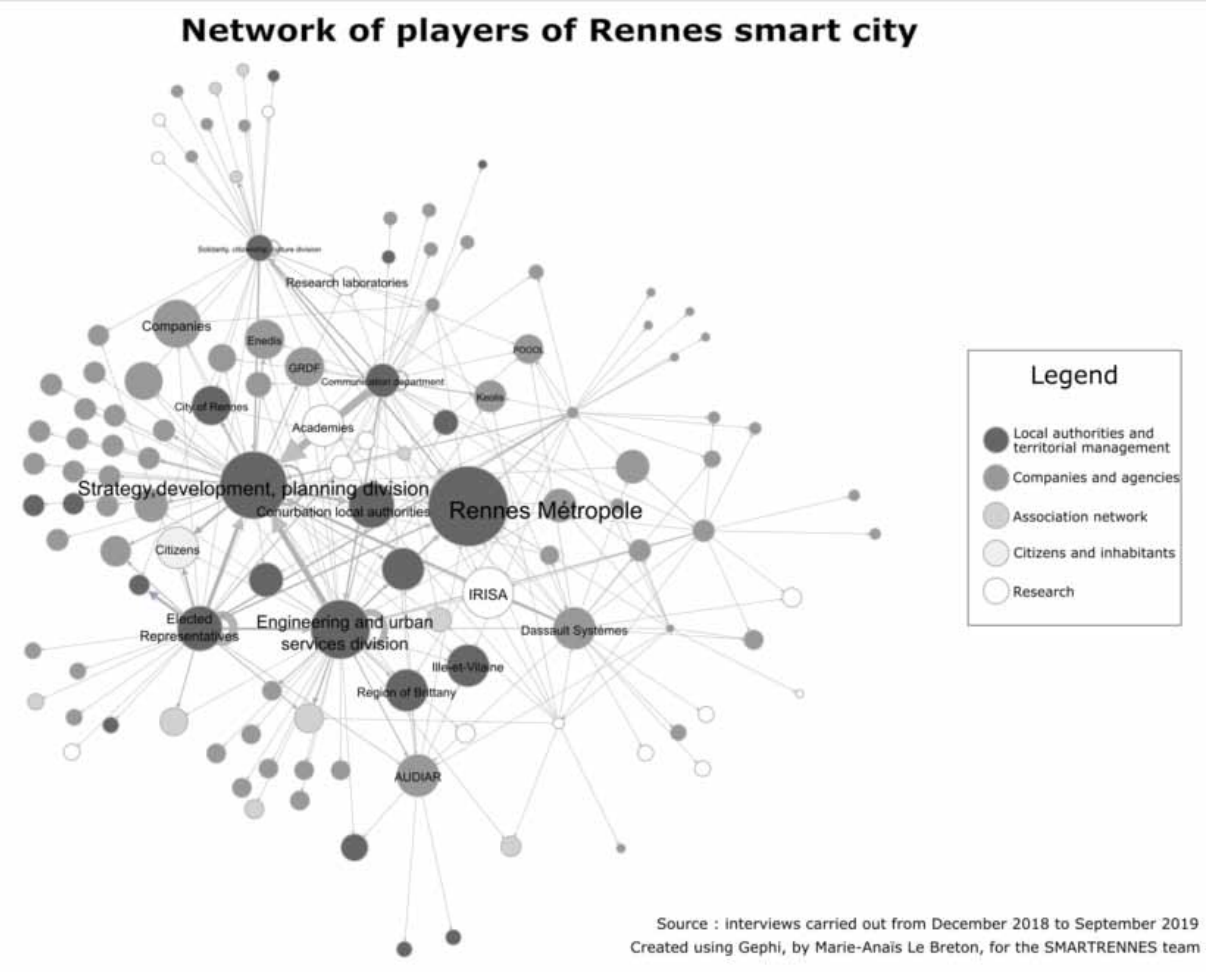


We note that the 'strategy, development and planning' node includes the smart city division and GIS direction, that explain his central position as leader of the initiative. The importance of the 'engineering and urban service' division is explained by its role in implementing the technical aspects of the smart city (sensors, data sets, etc.). However, it has a secondary role. This horizontal dynamic is made particularly visible in this visual means of representation: the elected representatives, the heads of directions, and the agents of the various departments are active participants of the smart city initiative. However, this metropolitan policy is not steered specifically by a 'superior' public entity in a downward vertical logic. We can note in fact that the players in the second ring of the graph, mainly companies and agencies, also have an 'activatable' network from which they produce projects that are part of the global 'smart city' initiative.

These results of the network analysis seem to confirm the fragmented dimension of the smart city of Rennes. We will now focus on synthesizing these results in an attempt to describe the 'Rennes style' smart city.

\section{DISCUSSION}

Different objectives has be assigned to integration of digitalisation in the context of urban governance studies. For example, Meijer \& Rodriguez Bolivar (2016) explain that much of the research ignores the relationship between technology and social structure. We have attempted here, through our qualitative approach, to show how the social structure influences the adoption and the non-adoption of a technological solution. The case of the deployment and then abandonment of the 3D Experiencityvirtual Rennes platform shows how experimentation allows the public player to retain decision-making. This result highlights the persistence of power issues in the governance of the smart city.

Finally, we can question ourselves if there is a Rennes-style smart city. The specificity is difficult to highlight in a monographic study. We have finally found many similarities with other work on European cities (Desdemoustier et al., 2019, Fernandez-Anez et al. 2018, Courmont A. \& Le Galès P., 2019, Nesti, 2020). The specificity of the Rennes case lies perhaps in the embedding of the smart city initiative in the context of a city where elected officials rely on experimentation to make their decisions over a long period of time. For ten years, the process of acculturation operates differently in relation to the value systems associated with the notion of smart city. For those interviewed, making sense of this territorial project is a matter for Rennes Métropole, and its elected representatives in particular. Strong political support is expected, which, while including and establishing relationships between all the relevant partners in the shared governance of innovation (private players, associations, civil society), must clarify the objectives and means of the smart city initiative. The challenge is therefore to verbalise a process that includes all the mechanisms in their diversity, they themselves being based on a plurality of players and partnerships already existing or to come. Where other cities are eager to communicate on their achievements, Rennes Métropole is waiting. As long as the political consensus is not reached, communication should not be rushed.

Moreover, our inquiry makes evident the fact that the motivation for smart city initiative is both a matter of voluntary redesigning public policy governance and a pragmatic will to organise something that is "irremediably happening". With François Ascher (2005), we can wonder whether the diverse projects that have emerged in recent years could let the public players say: "These events surpass us, let's pretend to be the organizers". But our analysis allows us today to state that the implementation of such an 'integrated vision' has come up against several issues.

The first one lies in defining the interest of the public player in taking action in this field. In fact, players from the digital industry have traditionally put forward the values of efficiency and productivity to justify the implementation of solutions to steer and monitor all the actions of a metropolitan area. These objectives do not seem to stand out in our survey as primary motivations, or in any case they are well below other issues such as those linked to the sustainable city, local democracy or even the sharing of a common political project. In this respect, the prefiguration approach of the Metropolitan 
public data service which has occupied the players interviewed over two years is an example of a process that voluntary allows time for reflection on the challenges before opting for a technological solution to be developed. Building a network of partners seems more important here than identifying performance goals or value creation.

Rennes Métropole appears here as the leading innovator of an inclusive smart city, whose responsibility is to put players in contact with each other (private sector, academics and associations) in a global project, which aims to use digital tools to serve land management and the involvement of everyone in territory development.

The case of Rennes also informs us about the role of local players in translating a 'globalised' ideal. In fact, Rennes smart city is none other than the continuity of an urban method of governance based on the involvement of public players and of public control of processes (Vion and Le Galès, 1998). What motivates the Rennes smart city initiative is above all the fear of inefficient control of the ongoing digital transition (from economic, democratic and social points of view). Thus, by carrying out actions in all fields, public players are ensured a 'tentacular' partnership with all stakeholders, allowing them to be at the centre of processes, even when these are completely private (industrial innovation, social innovation).

Far from confirming the local translation of a policy supported by the European Union, the French State or its regional partners, the approach in Rennes leads us rather to observe a consolidation of the urban regime (Stone, 1993) in this new theme of intervention that is the smart city. Thus, what is being played out at local level is certainly a form of reinvention of the ongoing digital transition, but like any alternative policy, it is necessary to await its results (Rumpala, 2018). The purpose behind the SmartRennes research is to help identify actions carried out and to tease out the underlying values in order to consolidate an alternative model to the neoliberal smart city.

\section{ACKNOWLEDGMENT}

The research was supported by The Plan Urbanisme Construction Architecture (PUCA), an interministerial agency of the French State $\left(n^{\circ} 2102512710\right)$. The authors would like to thank the staff of Rennes Metropole and the elected representatives that participated in the survey. We are grateful to the three anonymous reviewers who provided insightful comments and suggestions which allowed us to improve our manuscript. 


\section{REFERENCES}

Angelidou, M. (2014). Smart city policies: A spatial approach. Cities (London, England), 41(1), 3-11. doi:10.1016/j.cities.2014.06.007

Anthopoulos, L. G., \& Fitsilis, P. (2014). Smart cities and their roles in city competition: A classification. International Journal of Electronic Government Research, 10(1), 63-77. Advance online publication. doi:10.4018/ ijegr.2014010105

Ascher, F. (2005). La Société hypermoderne. Ces événements nous dépassent feignons d'en être les organisateurs. La Tour d'Aigues: Éditions de l'Aube.

Bailleul, H., \& Gibon, C. (2013, Sept.). Faut-il avoir peur de la ville numérique? Place Publique.

Caragliu, A., De Bo, C., \& Nijkamp, P. (2009). Smart cities in Europe. 3rd Central European Conference in Regional Science.

Chapuis, J.-Y. (2013). Rennes, la ville archipel. La Tour d'Aigues: Éditions de l'Aube.

Courmont, A., \& Le Galès, P. (2019). Gouverner la ville numérique. Presses Universitaires de France.

Desdemoustier, J., Crutzen, N., \& Giffinger, R. (2019). Municipalities' understanding of the Smart City concept: An exploratory analysis in Belgium. Technological Forecasting and Social Change, 142, 129-141. doi:10.1016/j. techfore.2018.10.029

Eveno, E. (2018). La ville intelligente: Objet au cœur de nombreuses controverses. Quaderni, 96(96), 29-41. doi:10.4000/quaderni.1174

Falco, E. \& Kleinhans, R. (2018). Digital participatory platforms for co-production in urban development: a systematic review. International Journal of E-Planning Research, 7(3). https://doi.org/10.4018/ IJEPR.2018070105doi: 10.4018/IJEPR.2018070105

Fernandez-Anez, V., Fernandez-Güell, J. M., \& Giffinger, R. (2018). Smart City implementation and discourses: An integrated conceptual model. The case of Vienna. Cities (London, England), 78, 4-16. doi:10.1016/j. cities.2017.12.004

Hall, R. E. (2000). The vision of A Smart City. Proceedings of the 2nd International Life Extension Technology Workshop.

Harrison, C., \& Donnelly, I. A. (2011). A Theory of Smart Cities. Proceedings of the 55th Annual Meeting of the ISSS-2011.

Hollands, R. G. (2008). Will the real smart city please stand up? City, 12(3),303-320. doi:10.1080/13604810802479126

Kleinhans, R., Van Ham, M., \& Evans-Cowley, J. (2015). Using social media and mobile technologies to foster engagement and self-organization in participatory urban planning and neighbourhood governance. Planning Practice and Research, 30(3), 237-247. doi:10.1080/02697459.2015.1051320

Kummitha, R., \& Crutzen, N. (2017). How do we understand smart cities? An evolutionary perspective. Cities (London, England), 17, 43-52. doi:10.1016/j.cities.2017.04.010

Le Corf, J. B. (2016). Les pratiques d'innovation de services des développeurs web dans les territoires: Le cas des projets Open Data. Communication \& Organisation, 50(2), 123-136. doi:10.4000/communicationorganisation.5387

Linders, D. (2012). From e-government to we-government: Defining a typology for citizen coproduction in the age of social media. Government Information Quarterly, 29(4), 446-454. doi:10.1016/j.giq.2012.06.003

Lucas, J.F. (2014). La numérisation de la ville et ses représentations. MCD Magazine, 77-85.

Lussault, M. (2018). L'allégorie de la smart city. Tous urbains, 23(3), 14-16.

Meijer, A., \& Rodríguez Bolívar, M. (2016). La gouvernance des villes intelligentes. Analyse de la littérature sur la gouvernance urbaine intelligente. Revue Internationale des Sciences Administratives, 82(2), 417-435. doi:10.3917/risa.822.0417 
Morozov, E., \& Bria, F. (2018). Rethinking the smart city. Democratizing Urban Technology. Rosa Luxemburg Stiftung.

Nam, T., \& Pardo, T. A. (2011). Conceptualizing smart city with dimensions of technology, people and institutions, Proceedings of the 12th Conference on Digital Government Research, 282-291. doi:10.1145/2037556.2037602

Nesti, G. (2020). Définir et évaluer la nature transformationnelle de la gouvernance des villes intelligentes: Observations issues de quatre cas européens. Revue Internationale des Sciences Administratives, 86(1), 23-40. doi:10.3917/risa.861.0023

Pinson, G. (2010). La gouvernance des villes françaises: Du schéma centre-périphérie aux régimes urbains. Pôle Sud, 32(1), 73-92. https://www.cairn.info/revue-pole-sud-2010-1-page-73.htm

Rumpala, Y. (2018). Intelligente autrement: de la "Smart city» à la « Fab city». Émergence d'un modèle alternatif de ville « intelligente » et logiques de reconfiguration du collectif urbain. Métropoles. doi:10.4000/ metropoles.5949

Santinha, G., \& Anselmo de Castro, E. (2010). Creating more intelligent cities: The role of ICT in promoting territorial governance. Journal of Urban Technology, 18(2), 77-98. doi:10.1080/10630732.2010.515088

Slotterback, C. S. (2011). Planners' perspectives on using technology in participatory processes. Environment \& Planning $B, 38(3), 468-485$. doi: $10.1068 / \mathrm{b} 36138$

Stone, C. (1993). Urban Regimes and the Capacity to Govern: A Political Economy Approach. Journal of Urban Affairs, 15(1), 1-28. doi:10.1111/j.1467-9906.1993.tb00300.x

Vion, A. \& Le Galès, P. (1998). Politique culturelle et gouvernance urbaine: l'exemple de Rennes. Politique et Management Public, 16(1), 1-33.

Walters, D. (2011). Smart cities, smart places, smart democracy: Form-based codes, electronic governance and the role of place in making smart cities. Intelligent Buildings International, 3(3), 198-218. doi:10.1080/1750 8975.2011.586670

Yovanof, G. S., \& Hazapis, G. N. (2009). An Architectural Framework and Enabling Wireless Technologies for Digital Cities \& Intelligent Urban Environments. Wireless Personal Communications, 49(3), 445-463. doi:10.1007/s11277-009-9693-4

\section{ENDNOTES}

1 "De la smart city au Territoire d'Intelligence(s)", Report to the Prime Minister on the future of smart cities, report written by Luc Belot (Deputy of the Maine et Loire department), April 2017 "De la smart city au Territoire d'Intelligence(s)", Report to the Prime Minister on the future of smart cities, report written by Luc Belot (Deputy of the Maine et Loire department), April 2017 Carcénac (2001) "For a citizens' electronic administration: contributions to the debate", French Governmental Report.

Source: http://francegeo.free.fr/ville.php?nom=rennes

Source: INSEE (for further information: https://www.insee.fr/fr/statistiques/1405599?geo=EP CI-243500139)

6 Source: Rennes Métropole (for further information: https://metropole.rennes.fr/rennes-metropolenumerique, consulted in September 2019)

$7 \quad$ The Plan Urbanisme Construction Architecture (PUCA) is an interministerial agency created in 1998 to advance the state of knowledge on regions and cities and to inform about public action. PUCA launches research incentive, action research and experimentation programmes and provides support for innovation and optimisation in the fields of land development, urbanism, habitat, architecture and construction. By Hélène Bailleul, for the SmartRennes team (ESO, PREFIcs and TVES laboratories), by Françoise Paquienseguy and Valentyna Dymitrova (ELICO laboratory, Sciences Po Lyon), by Ornella Zaza (LAVUE laboratory, ENSA La Villette), and by Sarah-Anaïs Achache (CITERES laboratory, University of Tours). 